\title{
HEREDITARY ESSENTIAL TREMOR IN BUENOS AIRES (ARGENTINA)
}

\author{
E. HERSKOVITS - E. FIGUEROA - C. MANGONE
}

SUMMARY - A descriptive trial of essential tremor in Buenos Aires city is proposed. It may be considered as the first one like this in Latin America. During a 15 years period, sixteen families with essential tremor diagnosis have been examined, making a total of 39 patients (20 males and 19 females). The disease was basically studied from its semiological, clinico-evolutive and therapeutical view point, following a protocol. Our results indicate a. The clinico-evolutive characteristics: its frequency (according to race, sex, social status, age of beginning and physiopathological type), morbility and mortality, evolution, prognosis, triggering factors, longevity and multiparity. b. The different treatment given to our patients with discussion of their pharmacokinetic and pharmacodynamic basis and evaluation of the best responses. In this matter, it is concluded that both primidone (750 mg/daily) and/or propranolol (160-240 $\mathrm{mg} /$ daily) are undeniably the drugs of first choice for the treatment of this disease. A comparison of the clinico-therapeutic features of this tremor in Buenos Aires and other cities is done. The study of this syndrome in Buenos Aires does not give: different results from those obtained in Europe and USA.

\section{TembIor esencial hereditario en Buenos Aires (Argentina).}

RESUMEN - Consideramos esta publicación como la primera sobre Temblor Esencial en América Latina. Todos nuestros pacientes eran inmigrantes o hijos de inmigrantes de los orígenes más comunes en nuestro país (España, Italia, Francia y Polonia). No se incluyeron pacientes indoamericanos. El reducido número de indoamericanos puros en Buenos Aires y sus alrededores debe tenerse en cuenta. El temblor hereditario esencial es entidad monosintomática, conocida durante más de cien años. Sus elenentos más importantes se describen progresivamente aquí $\mathrm{y}$ también, las dificultades terapéuticas que presenta. Durante un período de quince años, los autores pudieron seleccionar un total de 16 familias, con 39 casos de temblor esencial, estudiados básicamente desde el punto de vista clínico. Esto nos permitió confirmar el carácter del temblor, de tipo rítmico (4 a $10 \mathrm{c} / \mathrm{seg}$ ), preponderante en manos, especialmente en los dedos pulgar e indice, extensión del temblor a la boca, cabeza y eventualmente, a todo el cuerpo. La característica dominante y autosómica de la herencia también se demostró en nuestros pacientes. La edad de comienzo de esta entidad oscila entre $\operatorname{los} 20$ y los 40 an̆os, con una exacerbación en la quinta década de la vida. No hubo predominancia de ninguno de los sexos, ni de longevidad ni multiparidad. Esta enfermedad no produce la muerte y la incapacidad que acarrea no es muy importante. No parece existir una asociación entre esta entidad y otras enfermedades, excepto aquellas patologias desencadenantes como la tensión emocional y eventualmente, el alcoholismo como tratamiento aparente propuesto por el propio paciente para aliviar su sintomatología. La ubicación nosológica de esta enfermedad debe estar junto con los trastornos extrapiramidales, a pesar de los 5 casos existentes en la bibliografía mundíal sobre anatomía patológica, los que no presentaron alteraciones tales que justificaran el temblor en el sistema nervioso central. El diagnóstico dfferencial más importante debe hacerse en relación a la enfermedad de Parkinson o parkinsonismos. Este es un hecho simple ya que el temblor esencial no presenta los otros signos presentes en Parkinson excepto el temblor; además, esta enfermedad es hereditaria. El temblor esencial en manos responde mejor al manejo farmacológico que el temblor de

Hospital Juan A. Fernández, Unidad de Neurología Cerviño y Bulnes - Buenos Aires. 
cabeza, piernas o tronco. Los pacientes con temblor esencial tipo II responden mejor a la terapia con propranolol (40-80 $\mathrm{mg}$ t.i.d.) que los del tipo $\mathrm{I}$, pero ambos tipos de pacientes tienen respuesta similar a la primidona (250 $\mathrm{mg}$ t.i.d.). Concluimos que estas drogas son indudablemente la elección alternativa para el actual tratamiento de esta patología. El estudio de esta enfermedad en la ciudad de Buenos Aires no da resultados diferentes de los obtenidos en Europa y en los Estados Unidos.

The Argentine Republic is, together with Chile, the most austral country in South America; its surface is $2,800,000 \mathrm{Km}^{2}$, with a population of $30,000,000$ inhabitants. Buenos Aires Province has an area of $300,000 \mathrm{Km}^{2}$, with a total population of $14,500,000$ inhabitants, from them, approximately 10 millions belong to Buenos Aires City and environs ( $40 \mathrm{Km}$ radio) and they are the population which is focused in the present study.

The appearance of tremor in a patient is a known fact; but what is not so clear is when tremor is the only symptomatology presented by the patient and has a clear family origin. This neurological entity mainly consists of a tremor starting in youth or in the middle age, stationary during a period, but slowly progressing as year pass. It is common to find several members of a family with tremor. European literature and also American literature has taken into account these facts and a great number of papers related with this subject have appeared. During the last years, there were publications on this respect in all continents. Sir James Parkinson, in his publication of 1817 says that the expression 'agitating paralysis' has been vaguely used by physicians in general and that there was a disease corresponding to tremor of the members, previously observed by Galeno (A.D. 138-201) and by Sylvius de Laboe (A.D. 1614-72). He also mentions that Sylvius de Laboe distinguished between that tremor produced during a voluntary movement and that occurred when patient was at rest. This last kind of tremor was also named 'tremor coactus' by Voisser De Sauvages (A.D. 1763). Parkinson also refers to Gaupius as the first in mentioning the anteroflexion and the festinating walking, to which Sauvages called 'scellotrybe'. The term 'agitating paralysis' was firstly introduced in literature by Parkinson in his essay. It is fairly clear that all these references are related to a tremor having additional characteristics, and they are: difficulty in mobility and in walking and all the other symptoms that evidently make us to think of Parkinsin's disease and not other kind of tremors.

Perhaps one of the first mentions of a type of family tremor has been done by Most in 18367. Sanders in $1872^{6}$ described a patient with 'agitating paralysis' whose tremor began at 12 years old and persisted until his death at 66 years old. Trousseau in $1885^{6}$ pointed out that it is not necessary to confine the 'senile tremor' exclusively to elderly people and it may appear in the middle age or in adolescence. This is a conception which would let us think of an essential tremor, much more than a senile tremor. From the end of last century, a lot of authors have worked on this problem. Many of them should be appointed in our bibliography, some by their historical value, others by their relevant contributions to the subject. Therefore, we can sum up that since one hundred years ago, abundant titles from the semiological and physiological-anatomic point of view started to appear although not exhaustively. During the last years, major papers have not appeared and this is brought about by the few contributions to this disease, except for its treatment, where interesting facts can be observed. Nevertheless, as a general synthesis of this problem on essential tremor, we can say: 1 . it is a mono-symptomatic entity where the tremor occupies the dominant picture; 2. effectively, it has a genetic transmission and a slow progress; 3 . the pathological anatomy was not able to reveal which is the lesional site; 4. most of therapeutic improvements on tremor are obtained with mean doses of beta-blockers and/or primidone.

\section{MATERIAL AND METHODS}

Sixteen families with diagnosis of essential tremor have been studied for a 15 yearsperiod, making a total of 39 patients personally examined, 20 were male and 19 female. The diagnostic criterium was based on the tremor characteristics, the presence of a family origin, jts slow evolution and the absence of other extrapyramidal signs or symptoms 
suggesting Parkinson's disease, secondary parkinsonism or late cerebellum degeneration. A family tree was framed for each family and most of their members were personally examined by the authors. A neurological and clinical examination and routine laboratory determinations (including hepatogram and proteinogram) were performed. Kayser-Fleischer's ring was searched in all the individuals. Also, associated diseases were taken into account. The results have not decisive value for studying the frequency by three reasons: 1 . many patients with family essential tremor do not attend the medical consultation or are not sent to the Neurological Service due to its mild symptomatology; 2. vur special interest in this problem made us look for cases in the families of patients with tremor and also some patients were referred from other hospitals of Buenos Aires City; 3. patients without members of their [amily suffering from tremor were not included in our casuistic.

Semiology - Semiology of essential tremor was mentioned in some of its partial aspects by several authors $\left(\tau, t_{4}, 22\right)$. However, we should mention the exhaustive monography by Mac Donald Critchley $(i)$ in which he describes all its characteristics. In our experience we found that this disease is monosymptomatic, habitually in hands and specially in the first and second finger; it is observed not so unfrequently in mouth, tongue, inferior maxilla and head; exceptionally in the whole body. This tremor is of the action and postural variety.

AGE OF PATIENTS

AT EXAMINATION

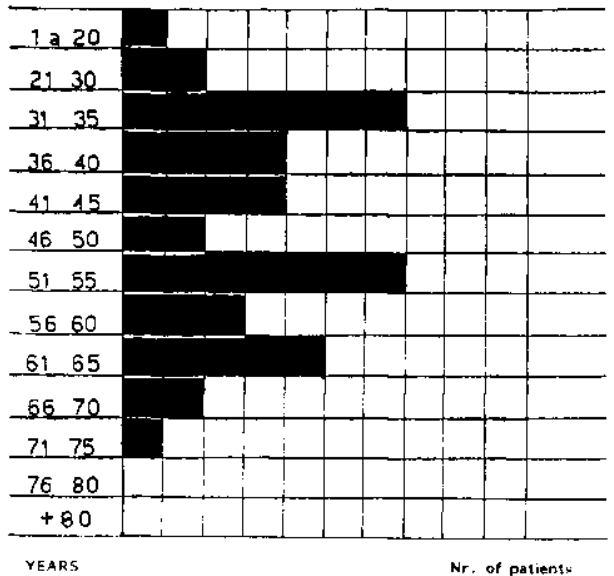

Fig. $x$ - Age and number of our patients at first examination.

Fig. 2 - Frequency curve of our patient's age at tremor onset.

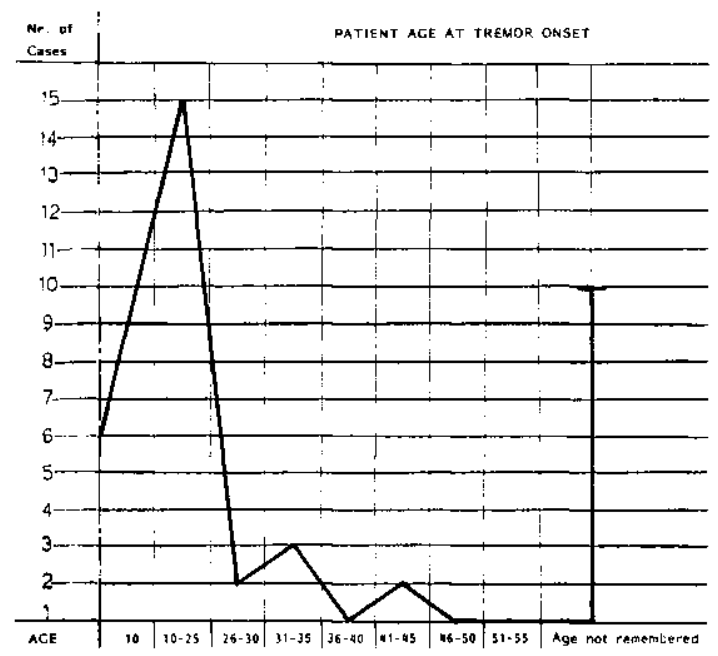




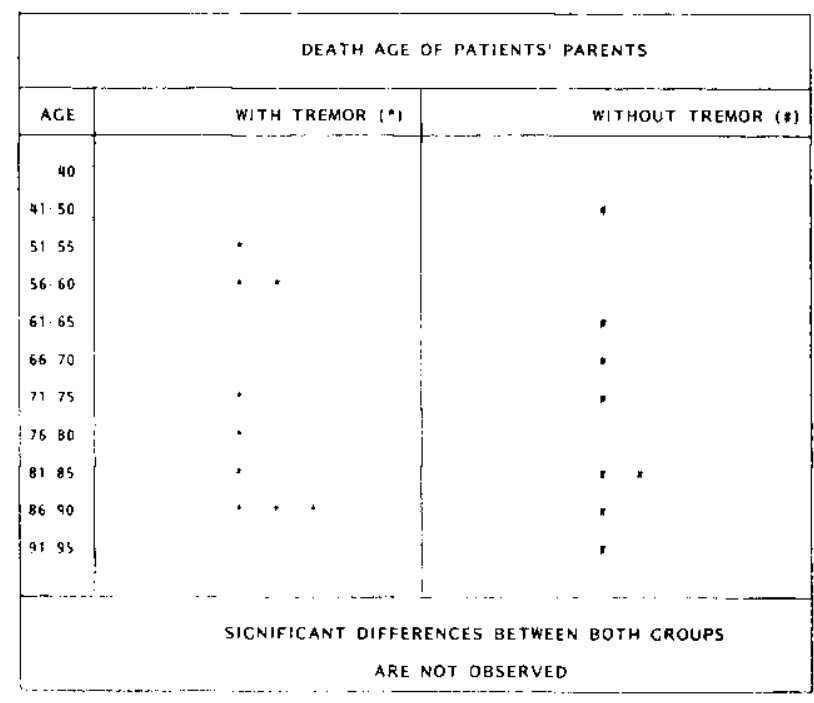

Fig. 3- Comparative table of death age of patient's parents with and without tremor.

FAMILIA 1 (BOR...) CASOS 1-2-3-4-5
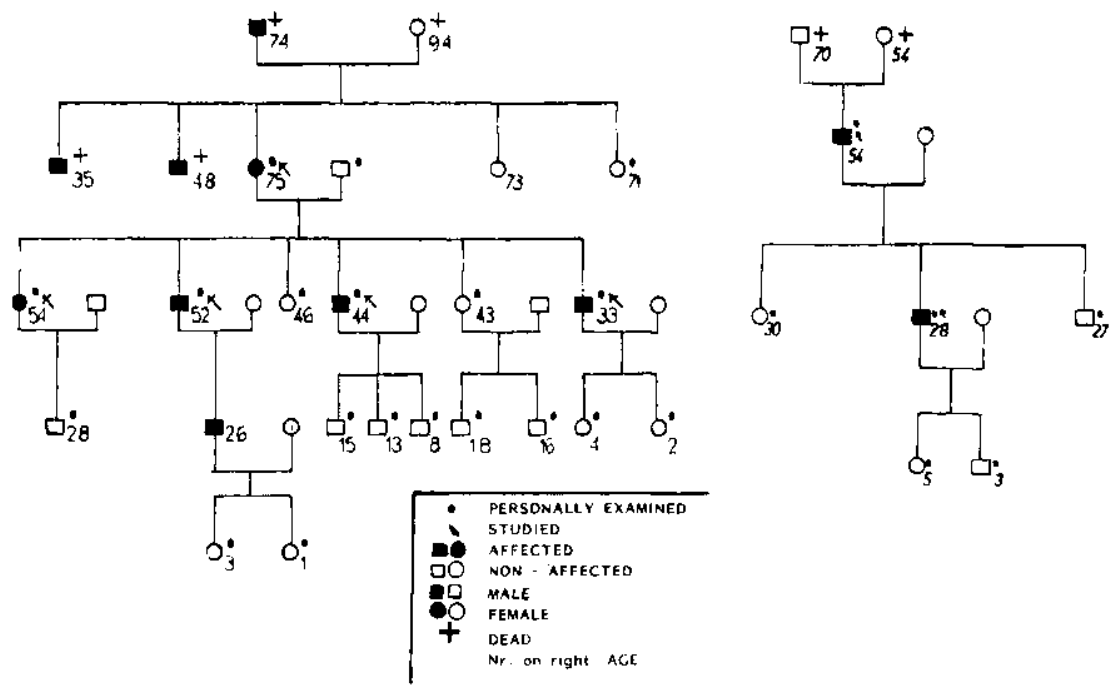

Fiy. 4 - Family tree of some of our patrients.

and is usually absent at rest. The action variety causes more disability in day to day functioning. In our cases we found that the 100\% (39 patients) had tremor in hands, either right, left or both, 16 individuals (near 40\%) had tremor of the head (either yes-yes or no-no variety) and only $5(15 \%)$ tremor of the voice. Tremor of lower extremities or trunk was less frequent. Tremor involving the head and lower extremities has a lower frequency that tremor in hands. We find usually different tremor frequency in each hand when it presents in both simultaneously. Stressful situations and physical or mental fatigue exacerbates essential tremor. It is very important to underline the absence of extrapyramidal signs, weakness, reflex alterations, stiffness of limbs, changes in the gait or posture. Only a slight $\operatorname{cog}$ wheeling can be find. We agree with the calssification's method of esgential 


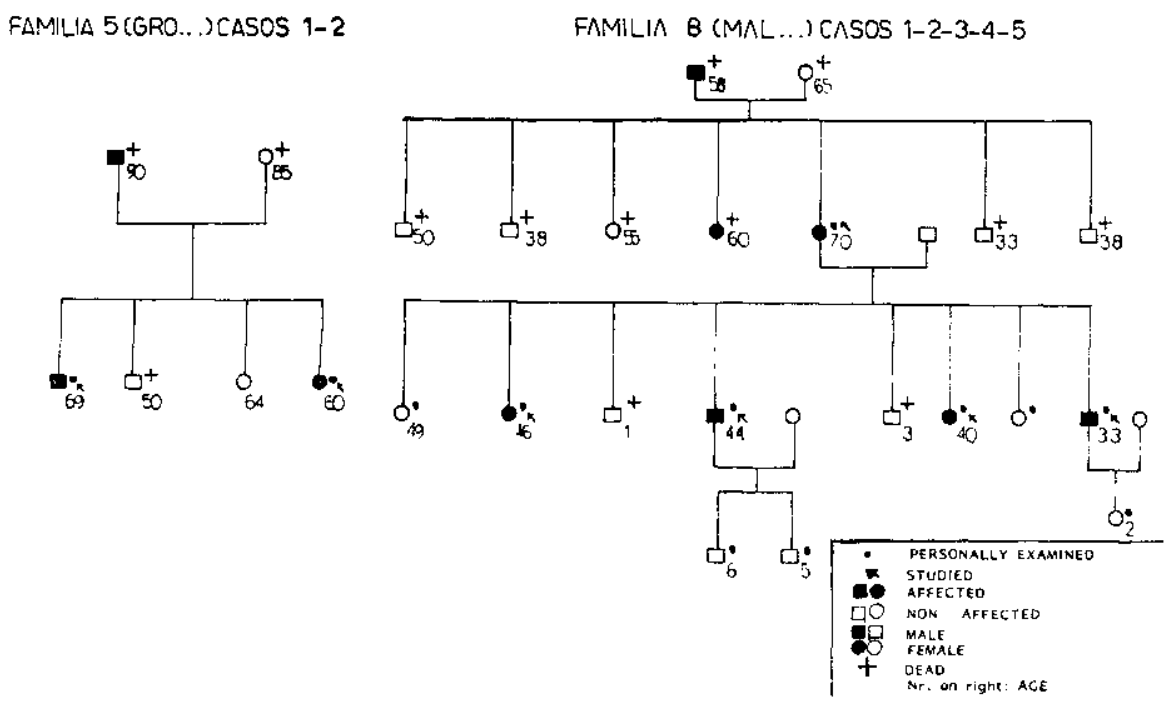

Fig. 5 - Family tree of some of our patients.

tremor of Marsden et al. in 4 types (18): I. Really and enhanced physiological tremor. characterized by high frequency $(8-12 \mathrm{~Hz})$ and low amplitude; pathophysiologically, there seem to be an alteration in the fine regulatory mechanisms of intra or extra fusal muscle fibers and the adrenoceptor has an important role in it; II. Characterized by a low frequency (5-7 $\mathrm{Hz}$ ) and a high amplitude tremor; perhaps, central mechanisms are pathophysiologically involved and are uninfluenced by the manipulation of peripheral reflex systems; most of the familial tremor belong to this group; this one usually responds to Beta-blocking agents; III. It is a severe pathological essential tremor, of slow frequency $(4-6 \mathrm{~Hz})$ and large amplitude; these patients have not family history; IV. It is a syinptomatic essential tremor, associated to other neurologic diseases, as for instance torsion dystonia, Parkinson's disease, and peripheral neuropathy.

We examined our patients systematically with a protocol: a. Tremor in upper extremities: hold arms outstretehed horizontally, with fingers extended; hand writing (a word, a sentence); drawing a spiral; drinking liquids. b. Tremor in head: yes-yes pattern: no-no pattern. c. Tremor in trunk and Juwer extremities (orthostatic tremor): standing; sitting (with legs at rest; with legs outstretched). We evaluate the deficits with a disability scale: 0 , normal (no tremor); 1 , mild; 2 , moderate; 3 , severe. Whon making forefinger-nose, forefinger ear, polish of dorsum of hands and speedy counting of finger tests, a slight final tremor with attenuated dysmetry - reminding in some way a minimal neo-cerebellum syndrome was observed. Other aspects of the neurological examination were completely normal.

\section{RESULTS AND COMMENTS}

Our intention is to divide our results into scveral sections, always considered interesting in this disease, since there were old controversies regarding longevity, multiparity, association with other diseases, race, onset age and therapeutic approaches.

Race, sex, social status, age of beginning - Race: All the patients studied were inmigrants or sons of inmigrants from the most common origin in Buenos Aires City: Spain, Italy, Syria, France and Poland. There was not any patient from undubitable indoamerican origin; that is to say, all our patients are from caucasic origin. It is worth noting that the number of pure indoamericans in Argentina is reduced. As far as we know, there have not been cases - communicated - of family essential tremor in the black or yellow race. This does not mean they do not exist, because for eventual reasons, african or asiatic publications could appear later. 
Most of published cases correspond to Western Europe and a minority to Eastern Eırope and North America. From the study of published cases, racial predominance was not observed. Sex: There is a slight predominance of males in most of publicitions with a moderately numerous casuistic $6,16,22,23$. In our cases, 20 were males and 19 females. Social status: Our patients are distributed in the usual way in all so ial groups. Age of beginning: Considering our casuistic, the beginning of symptoms in most of patients is before 20 years old diminishing up to 45 years old. It is worth ob ierving that in $25 \%$ of cases, the beginning date of tremor cannot be established (F.gs. 1 and 2). Dana 7 and Amore-Bonelli 1 postulated that essential tremor starts at middle age. Pintus 23 and Critchley 6 consider two beginning periods: at 20 and at 40 years old.

Mortality, evolution and prognosis - Mortality: It was not proved that the essential hereditary tremor provokes death in patients suffering from it nor it indirectly induces death, nor it produces some special discapacity, except the disturbance itse if produced by tremor. Evolution: It is a slowly progressive disorder that is generally exacerbated in the middle age of life, with abrupt aggravation of symptomatology; afterwards, it continues in slow progression. However, Critchley 6 postulated that it was not progressive and Denny-Brown that it was a stationary disease. Thirty $(77 \%)$ of our patients present a slowly progressive form, increasing amplitude or spr ading tremor to other parts of the body. Prognosis: Although no author referred specially to this item, we can establish according to our casuistic, that it is good qual vitam, in spite of being the tremor slowly progressive.

Triggering factors, longevity, multiparity, associated conditions - Triggering facturs: Cheylard 4 does not associate the tremor to triggering factors while other authors do 8,12, with whom agree. It is believed that it can be triggered by: stress, alconol, coldness, fatigue, and fear, as it happens with other types of tremor which can also be triggered by these factors (for example, the adrenalynic tremor and the tirotoxic tremor). Longevity and multiparity: From our cases we proved that there are no evidences of these items, since longevity and multiparity of the patients do not differ from the group without tremor. Multiparity is not observed among the patients and their first degree relatives who have had children. The children average per fertile couple is 2.9. Both items were postulated by Charcot 3 and others, while Pintus 22,23 and other authors refused them. Association with other syndromes and diseases: According to several authors 7,20, the more frequent associations with the essential hereditary tremor are: neurosis, psychosis, drunkness, epilepsy and Charcot-Marie-Tooth disease. Some authors suggest that these patients have more chances to develop Parkinson's disease. We have found it associated with two cases of epilepsy and six cases of alcoholism. We have not found any special association of this disease with Parkinson's disease.

Frequency, genetics, pathologic anatomy - Frequency: The family essential tremor is an old disease at such extent that for example, there was not any publication on it in Latin America, except one from one of the authors of this paper 24. This lack of publications is partly a consequence of an appreciation mistake, since many essential tremor are erroneously included into other conditions, as for instance: parkinsonian syndromes, states of emotional tension, and alcoholic tremors. On the other hand, the lack of interest in a disease of so slow course and not very injuring may be another cause of the absence of publications on this subject. There are isolated works that do not allow us to have an idea on the frequency and morbility of the affection. The only publications with a detailed genetic study, which permit to draw some conclusions from the subject, are those from Pintus 22,23, Larsson and Sjörgen 16 and Rautakorpi et al.25. Minor 19 stated that the essential tremor was more common in Russian than in European West, without giving precise data for this hypothesis and without finding later its confirmation 6,14. Larsson and Sjörgen 16 found a total of 210 patients with tremor, 81 out of them were personally examined in Vasterbotten County (Sweden) in a genetic study on a total population of 7,499 inhabitants. This paper is very important to determine the type of genetic transmission of the disease. According to their figures, morbility would be of 1.9 for men and 0.9 for women. Genetics: The genetic condition of this disease is undoubtful. Through the reading of our casuistic, it comes out evident that the transmission of this disease is dominant autosomal. One of the most important published papers on this respect is that of Larsson and Sjörgen 16. They were able to determine that in this disease there is not anticipation phenomenon (the onset of the disease occurring at a gradually younger age in consecutive generations) and that an heterozygota 
transmission is probable and it is a dominant autosomal heredity. Mendelian analysis confirms these conclusions: this heredity is dominant, mono hydrid, autosomal, with no differences between symptoms of heterozygotic and dominant homozygotic groups. Taking into account all conclusions on genetics of these authors, these are the most important and are well demonstrated in the difficult and complex study performed by them. However, other authors previously arrived to similar conclusions.

In the families studied by us we found the same situation, so we confirm previous authors' statement. We include the family tree of four of our patients (Figs. 4 and 5). Pathologic anatomy: Pathological changes underlying this condition are uncertain and there are only few published cases with morbid pathology analysis. However, the structure abnormalities found here are not different from those in patients without tremor. One of us (E.H.) published 13 a case on a patient presenting small softenings in putamen, moderate atheroma in vessels and arteriosclerosis.

Differential diagnosis - Undoubtedly, the first diseases from which family hereditary tremor should be differentiated is Parkinson's disease and parkinsonism. In typical cases of Parkinson's disease, there is no difficulty because, besides tremor, this disease presents rigidity, hypokinesia, neurovegetative disturbances, postural and and walking disturbances, endogenous and exogenous depression and ocasionally, psychic deterioration. These signs are not present in the family hereditary tremor. Some few parkinsonian patients may have family origin. This would make us think of a family hereditary tremor, but this fact is put aside through the neurological examination. Some greater difficulty may be found in Parkinson's disease or parkinsonisms whose onset is the predominantly trembling form and where the remaining extrapyramidal signs have not appeared yet or are scarcely manifest. In these cases, the beginning age, later in Parkinson, can determine the diagnosis, perhaps, observations of patients during some time is the most convenient in order to see the appearance or not of other symptoms or signs. From a therapeutic point of view, drugs improving Parkinson's disease or parkinsonisms, except propranolol have no effect on essential tremor 2,26. The adrenaline-induced tremor, such as those produced by anxiety and by fatigue, have the same clinical appearance than the physiological tremor. With respect to alcoholic tremor, anamnesis and alcoholic intake antecedents are evidently very important to aid diagnosis. However, great diagnostic difficulties can arise in a group of patients who like to take alcoholic drinks, justly because they mitigate tremor. The question is if the patient takes the alcoholic drink to mitigate tremor, if he drinks to mitigate his alcoholic thirst or if both kinds of tremors are already simultaneously present. It is a known fact that a significant number of patients with essential hereditary tremor are prone to drink, justly because they mitigate this tremor. When there are non-alcoholic relatives with tremor, diagnosis is oriented to Essential Tremor.

Therapeutic approaches - As essential tremor progresses slowly, we prefer a systematic and periodical control of our patients beginning drug therapy only when the tremor acquires considerable magnitude or is demanded by the patient. About $55 \%$ of our casuistic observed a reduction in amplitude of tremor with small quantities of ethanol, phenomenon that we never use as diagnostic or therapeutic method.

We have done different clinical trials with our patients prefering the management of essential tremor with: (a) basic therapeutic drugs (beta-blockers, primidone, clonazepam), and occasionally (b) coadjuvant therapy (psychological assessment; sedatives: benzodiazepine drugs that decrease anxiety and agitation reducing adrenergic enhancement during stress. They are useful drugs in chronic anxiety neurotic patients). Beta-blocking drugs: Today propranolol is the drug of first choice in the management of essential tremor. It was introduced in 1960's supporting the idea of blocking tremorgenic action of the endogenous adrenergic derivatives during stress. Then, it was necessary to recognize whether the action was at a central or peripheral level and which adrenergic receptor was involved in this tremorgenic response. Although the different clinical trials and the basic experiments done up till now, too many controversies persist. It is undeniable that the beta-adrenoreceptor is involved in the tremorgenic action of catechol derivates (nevertheless alpha adrenoreceptor by probable central pathways can influence also, as it was demonstrated by Mai et al.17 with an alpha blocking drug: thymoxamine). The beta-adrenoreceptor can be located within the central nervous system (CNS) or in the periphery and classified according to its pharmacodynamic characteristics in beta ${ }_{1}$ and beta $a_{2}$ subtypes. In the periphery there are beta ${ }_{2}$ receptors at intra and extrafusal muscle fibers and a 
sympatomimetic drug like adrenaline would induce tremor or would exagerate essential tremor by a direct effect on these receptors producing an increase in muscle spindle sensitivity and alterations in muscle contractility 5 . Propranolol and derivates drugs are able to have tremorlytic action inhibiting that phenomenon by blocking beta $_{2}$ receptors. In spite of this, it cannot be affirmed that the beta receptor sites $^{2}$ are the only locus of tremorlytic action of propranolol 10. The beta-blockers have the following pharmacologic characteristics: 1. Selectivity — non selective beta

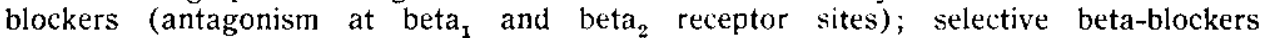
(antagonism at beta ${ }_{1}$ or beta beceptor sites); beta $_{1}$ selective blockers: metoprolol; beta $_{2}$ selective blockers: ICI 118551, LI 32468. 2. Lipid solubility - high lipid solubility: rapid absorption across blood brain barrier, so rapid penetration in CNS: propranolol, sotalol; poor lipid solubility: poor passage of the drug across the blood brain barrier, and so a slow penetration in CNS: atenolol, ICI 1I8551. 3. Intrinsic sympatomimetic action (I.S.M.A.) - without I.S.M.A.: total antagonism - propranolol; with I.S.M.A.: partial agonism - pindolol. According to these pharmacological characteristics we can make the following considerations: a. Even if non selective adrenergic beta-blocking drugs and selective beta, reduce essential tremor amplitude to some degree, there is strong clinical evidence that beta., blocking drugs are the most effective in tremorlytic action 27 . b. Only in chronic administration is important the CNS penetration because an additional central action appears. When we administrate a beta-blocker there is an acute response 15 days later mediated by a central action 15; so, additional effect of the drug at central receptor sites may result in greater therapeutic gain. c. Intrinsic sympathomimetic activity is a disadvantage in terms of drug therapy in essential tremor, specially in chronic administration because it gains beta agonism 10. In our personal experience, we use propranolol because no other drug was yet described in prolonged trials to be more efficient. There is a great variability in the doses (40-300mg) by day, that may be due to the first pass metabolism of propranolol (although we know that there is no correlation between plasma concentration of propranolol and the therapeutic control of the symptomatology). We observed better response between $40-80 \mathrm{mg}$ t.i.d.; we verified a reduction in the amplitude of tremor being the type II essential tremor patients (high amplitude, low frequency) the best responders. We are able to say that about $75 \%$ of our patients (30) cases) have a positive response with clear reduction in the amplitude of tremor. We have similar clinical responses with the long-acting propranolol which swas preferred by most of our patients because of its once daily dose. Primidone: Since O'Brien reports 21 primidone is an alternative useful drug in essential tremor treatment. Its efficacy is similar to that of propranolol and better in some patients in whom tremor was able to be supressed, phenomenon never seen with beta-blockers 10 . Tremor in hands responses better than tremor in head and trunk where it is almost unresponsive. Its mechanism of action is unknown but primidone acts by itself in essential tremor and not by its metabolites PEMA and phenobarbital because previously to have significant concentration of them, the drug las tremorlytic action 15. In our personal experience, we have widely used primidone not only instead of propranolol but as a first choice, principally when we have a high frequency-low amplitude tremor patient. It is well known the acute intolerance to primidone, so we used small doses initially, increasing them slowly so to generate enzymatic induction by the liver facilitating in this way its metabolization and reducing toxic acute manifestations. Treatment is always begun with $62.5 \mathrm{mg}$ and weekly increased up to $750 \mathrm{mg}$ daily, supporting in this way the best doses we think: $250 \mathrm{mg}$ t.i.d.; this staggered augmentative method is only stopped when the patient asks for it or adverse reactions appear, such us ataxia, nausea and vomiting, giddiness, somnolence. Primidone + Propranolol: We observe a useful but little additive effect combining both drugs as an additional synergism. The treatment is started with low doses of primidone $62.5 \mathrm{mg}$ at bedtime so to increase it to $250 \mathrm{mg}$. Then propranolol is added at $40 \mathrm{mg}$ three times a day to a maximum of $80 \mathrm{mg}$ three times a day or a long acting propranolol used if once daily administration is preferred. We need some more experience in this method but we also checked up that the risk of the adverse reactions is increased approximately about $10-15 \%$. In spite of this, a little pool of our patients has been benefited by the combinative form of administration. Clonazepam: Clonazepam is a benzodiazepine drug. We use the other benzodiazepines as sedatives but this one may have proper mechanisms of action that make it useful in some cases of orthostatic tremor. Two of our patients, with this special form of essential tremor had a dramatic response to $2-4 \mathrm{mg}$ daily of it as also was reported by Wee et al.28. 
Conclusions - 1. We consider this publication as the first one on Essential Tremor in Latin-America. All of our patients were inmigrants or sons of inmigrants from the most common origins in our country (Spain, Italy, Syria, France and Poland). There were no indoamerican patients included. The very small number of pure indoamericans in Buenos Aires should be pointed out. Basically, inmigration in Buenos Aires and surroundings is composed by a third from Spanish origin, another third from Italian origin and the remaining third from the other European countries and Middle East countries. 2. The essential hereditary tremor is a monosymptomatic entity, known for more than one hundred years ago. Its more important elements were progressively described here and also, the therapeutic difficulties it presented. 3. During a fifteen years period, the authors were able to select a total of 16 families, with 19 cases of essential tremor, studied basically from the clinical point of view. This allowed us to confirm the character of the tremor, of rhythmic type (4 to $10 \mathrm{c} / \mathrm{sec}$ ), preponderant in hands, specially in thumb and index finger, extension of tremor to mouth, head and eventually, to the whole body. The dominant and autosomal characteristic of heredity was also demonstrated in our patients. 4. The beginning age of this entity ranges between 20 to 40 years, with an exacerbation in the fifth life decade. There was no predominance of either of both sexes nor longevity nor multiparity. Mortality is not produced by this disease and the incapacity brought about is not very important. 5. There not seem to be an association between this entity and other diseases except those triggering pathologies, like emotional tension and eventually, the alcoholism as apparent treatment proposed by the own patient to mitigate his symptomatology. 6 . The nosologic placement of this disease should be together with the extrapyramidal disorders, in spite of the five cases existing in the world bibliography on pathological anatomy, which were not able to present alterations justifying tremor in the CNS. 7. The more important differential diagnosis should be made in relation to Parkinson or parkinsonisms. This is a simple fact since essential tremor does not present any of the other signs present in Parkinson except tremor; besides, this disease is hereditary. 8. Essential tremor of hands responds better to pharmacological management than tremor of head, legs or trunk. Type II essential tremor patients correspond better to propranolol (40-80mg t.i.d.) therapy than Type 1 do, but both types tremor patients have similar responses to primidone (250mg t.i.d.). We conclude that these drugs are undoubtedly the alternative choice for the actual treatment of this pathology. 9. The study of this disease in Buenos Aires city does not give different results from those obtained in Europe and United States.

\section{REFERENCES}

1. Amore-Bonelli $\mathrm{G}$ - Contributo alla conoscenza del tremore essenziale ereditario. Riv Sper Preniat 23:58 (Abst: Rev Neurol 6:372, 1898).

2. Balla J - Treatment of essential tremor with propranolol. Lancet 1:205, 1973.

3. Charcot JM - Quelques remarques à ce propos: sur le tremblement héreditaire et le tremblement senile. Leçons du Mardi. I. Policlinique du Mardi 24 Julliet 1888, Paris, pg 563.

4. Cheylard $\mathrm{M}$ - Contribution a l'étude du tremblement essential héreditaire. These de Montpellier ne 26, 1909. (Abst: Rev Neurol 19:368, 1910).

5. Cleeves L, Findley L - Beta-adrenoreceptor mechanism in essential tremor: a comparative single case study of the effect of a non-selective and a beta-2 selective adrenoceptor antagonist. J Neurol Neurosurg Psychiat 47:976, 1984.

6. Critchley E - Observations on essential (heredofamilial) tremor. Brain 72(2):113, 1949.

7. Dana C - Hereditary tremor, a hitherto undescribed form of motor neurosis. Amer $J$ Med Sci $94: 386,1887$.

8. Davis $\mathrm{CH} \mathrm{Jr}$, Kinkle EC - Benign essential (heredofamilial) tremor. Arch Int Med $87: 808,1951$.

9. Denny-Brown D - A case of rubral tremor. Proc Roy Soc Med 31:718, 1938.

10. Findley L - Drug treatment of essential tremor. Clin Neuropharm 9 (suppl 2):61, 1986. 
11. Findley L, Cleeves $L$, Calzetti $\mathbf{S}-$ Primidone in essential tremor of hands and head: a double blind controlled study. J Neurol Neurosurg Psychiat 48:911, 1985.

12. Flatau G - Uber hereditären essentiellen Tremor. Arch Psych Nervenkr 44:106 (Abst: Rev Neurol 17:417, 1908).

13. Herskovits E, Blackwood W - Essential (heredofamilial) tremor: a case report. J Neurol Neurosurg Psychiat 32:509, 1969.

14. Hehrer $\mathbf{F} \rightarrow$ Uber das erbliche Zittern, Zittern und die Bedeutung von Langlebigkeit, Kinderreichtum und $Z$ willingsgeburten in Sippen mit heredodegenerativen Nervenleiden. Dtsch Ztschr Nervenh 114:165, 1930.

15. Kolter W, Royce V - Efficacy of primidone in essential tremor. Neurology 36:121, 1986.

16. Larsson $T$, Sjörgen $T-$ Essential tremor: a clinical and genetic population study. Acta Psychiat Neurol Scand 36 (suppl 144), 1960.

17. Mai J, Olsen RB - Depression of essential tremor by alpha adrenergic blockage. J Neurol Neurosurg Psychiat 44:1171, 1981.

18. Marsden CD, Obeso J, Rothwell JC - Benign essential tremor is not a single entity. In Yahr M (ed): Current Concepts in Parkinson Disease. Excerpta Medica, Amsterdam 1983, pg 31 .

19. Minor L - Uber das erbliche Zittern. Ztschr ges Neurol Psychiat 99:586, 1925.

20. Myle G, Van Bogaert L - Du tremblement essential non-familial. Mschr Psychiat Neurol 115:80, 1948.

21. O'Brien M, Upton AR, Toselanal TA - Benign familial tremor treated with primidone. $\mathrm{Br}$ Med J 281:178, 1981.

22. Pintus $G$ - Sulla transmissione ereditaria dell tremor essentiale. Riv Patol Nerv Ment $39: 1,1931$.

23. Pintus $\mathrm{G}$ - Sul tipno «macrobioticus multiparus» del tremor essenziale. Riv Patol Nerv Ment 51:114, 1938.

24. Poch GF, Herskovits E - Temblor esencial. In Poch G (ed): Errores Genéticos del Metabolismo. López Libreros, Buenos Aires, 1971.

25. Rautakorpi I, Takala J, Martila RJ, Sievers K, Rinne U - Essential tremor in a Finnish population. Acta Neurol Scand 66:58, 1982.

26. Sweet RD, Blumerg J, Lee JE, Mc Dowell FH - Propranolol treatment of essential tremor. Neurology 24:64, 1974 .

27. Teravainen $\mathrm{H}$, Hutunen $\mathrm{J}$, Larsen $\mathrm{T}$ - Selective adrenergic beta 2 receptor blocking drug ICI 118551 is effective in essential tremor. Acta Neurol Scand 74:34, 1986.

28. Wee A, Subramony M, Currier $M$ - Orthostatic tremor in familial essential tremor, Neurology $36: 1241,1986$. 